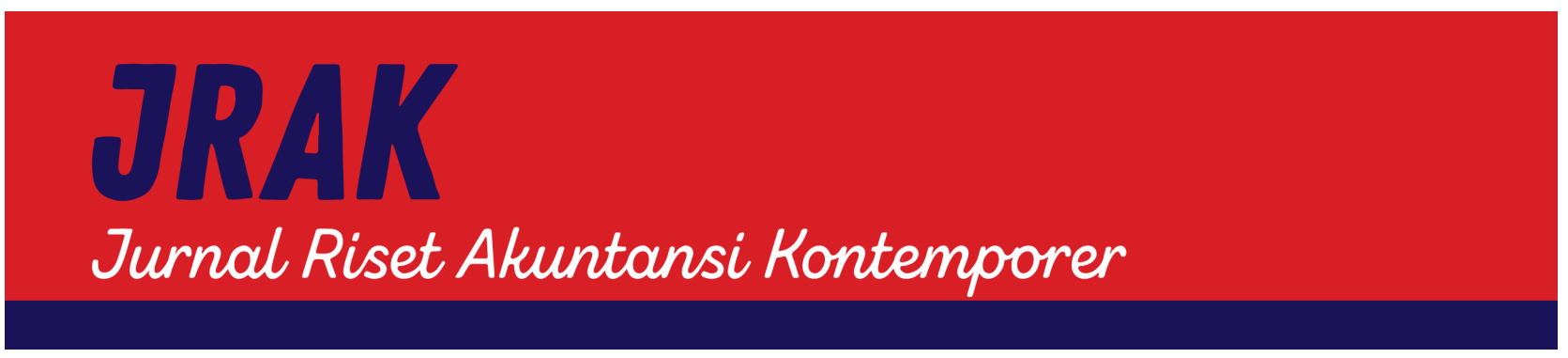

\title{
ETHICS, EDUCATION LEVEL, AND PROFESSIONAL SKEPTICISM ON AUDIT QUALITY
}

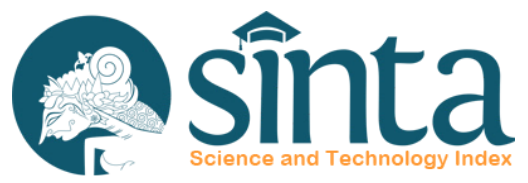

https://journal.unpas.ac.id/index.php/jrak/index

Mega Rianita Kartika ${ }^{1} \bowtie$, Fitriana ${ }^{2}$, Farida Yuliaty $^{3}$

1,2,3 Universitas Sangga Buana Bandung

$\checkmark$ megariantcika@gmail.com

J1 PH.H. Mustofa (Suci) No.68, Cikutra, Kec. Cibeunying Kidul, Kota Bandung

\section{Article Info}

History of Article

Received: 23/2/2021

Revised: 3/3/2021

Published: $25 / 4 / 2021$

Jurnal Riset Akuntansi Kontemporer

Volume 13, No. 1, April 2021, Page 32-36

ISSN 2088-5091 (Print)

ISSN 2597-6826 (Online)

Keywords: ethics; education level; professional skepticism; audit quality

\begin{abstract}
In the implementation of government financial management, audit process is carried out by the inspectorate with the purpose to produce a quality audit. One of the indicators is the inspection report is submitted on time, however in the last 3 years the reports submitted by the Inspectorate of West Java Province have been late. The purpose of study was to determine the influence of ethics, education level, and professional skepticism on audit quality in the Inspectorate of West Java Province. This study conducted with a total 70 auditors with descriptive and verificative research method. Data collection using questionnaires and was analized by multiple linear regression. This study used multiple linear regression analysis. The results show that ethics, education level, and professional skepticism has an influence on quality audits both partially and simultaneously.
\end{abstract}

\section{INTRODUCTION}

In this era of democracy, the government is required to be more transparent in running its rules especially in managing its finances. In the implementation of government financial management, internal audit or internal supervision of the central and regional governments is carried out by Aparat Pengawasan Intern Pemerintah (APIP). The inspectorate is part of the APIP which has the main task and function of supervising government administration. The Inspectorate of West Java Province, of course, must be able to take corrective actions for irregularities in the implementation of government affairs and administration in the regions if they are not in accordance with the prevailing laws and regulations. One of the objectives of the audit process is to produce quality audits. In the government sector, a quality audit is needed in the management of government finances so that it can run well, because if the quality of the audit is low, it can open up gaps and space for government organizations to deviate from the use of the budget.

According to Standar Pemeriksaan Keuangan Negara (SPKN) in 2017, one of the indicators of audit quality is that the inspection reports are submitted on time, however the performance of the Inspectorate of West Java Province must be doubted because many reports were submitted late and even not yet finished. MENDAGRI Regulation concerning Guidelines for Supervision Procedures for the Implementation of Regional Government Number 23 of 2007 states that no later than 15 (fifteen) days after completing regular examinations, the 
Examining Team is obliged to complete the revised examination report. In fact, there are still some Examining Teams that cannot fulfill this indicator. The rate of completion of LHP on time from each year is still very low.

This could lead to doubts about the competence of auditors at the Inspectorate of West Java Province because they were unable to complete the inspection on time. Competence is one of the principles of professional ethics that auditors must have in terms of professionalism and competence can be obtained by a person through the education level, with the high education level that auditors have, it is hoped that the competence of auditors will increase.

Another indicator of audit quality is that the report produced must be objective according to the facts in the field, but this seems less appropriate if we compare the LHP completion time with the opinion obtained from the BPK. Many cities and districts have received the WTP opinion, but the reports are too late or even finished. In 2016 the Sukabumi City Government has not completed the LHP but received a WTP opinion, in 2017 many municipal and district governments were late in submitting LHP but WTPs such as Banjar City Government, Bogor, Cirebon, Tasikmalaya, Bandung Regency Government, Bekasi, Bogor, Ciamis, Garut, Indramayu, Karawang, Majalengka, Kuningan, Pangandaran, Sukabumi, and Tasikmalaya Regency Government as well as in 2018 the Sukabumi Regency Government and Bandung Regency Government have not completed the LHP but received WTP. From this there are doubts about the application of auditors' professional ethics in terms of independence or objectivity. Through ethics, it is expected that the auditors will have professionalism and professionalism which requires the auditors to exercise professional skepticism. Professional skepticism is an attitude that includes a questioning mind and a critical assessment of audit evidence. (Arens, et al. 2017) A skeptical auditor will not simply accept the explanation from the client but will ask questions to obtain reasons, evidence and confirmation regarding the object in question.

There are several problems identified in this study namely that the results of the Inspectorate of West Java Province audit are not yet optimal, seen from the late reports submitted, there are still disturbances from both internal and external in conducting audits that can affect professional ethics. In terms of independence, employees at the Inspectorate still lack experience in conducting supervision and the low level of skepticism on auditors.

This study conducting at the Inspectorate of West Java Province with the aim of knowing, auditor ethics, education level, skepticism, and audit quality of how much is the effect of ethics, educational level, and professional skepticism of auditors on audit quality simultanously and partially.

Research conducted by Ningsih and Nadirsyah (2017) states that auditors' professional skepticism and audit ethics affect audit quality both partially and simultaneously. In addition, research conducted by Nurjanah and Kartika (2016) states that professional ethics and skepticism have a positive and significant effect on audit quality. The same result is stated in a study conducted by Futri and Juliarsa (2014) that the education level and professional ethics have a positive effect on audit quality.

\section{METHOD}

The population of this study were 85 auditors who worked at the Inspectorate of West Java Province, due to time constraints, the sample was selected using the Slovin formula in order to obtain 70 auditors of the Inspectorate of West Java Province. The sampling technique in this study used simple random sampling.

The method used in this research is descriptive and verification methods through qualitative and quantitative approaches. Descriptive and verification methods are used in this study because the researcher wants to get a picture, relationship pattern and influence between each research variable. The qualitative approach to this research is because the instrument used is in the form of a questionnaire containing questions or statements to the respondents, then quantified using a Likert scale for each answer to the question or statement raised in the questionnaire.

\section{RESULT}

Data quality testing was carried out to ensure that data were valid and reliable. The validity test was carried out using the Pearson Bivariate correlation and the results were obtained if $r_{\text {count }} \geq r_{\text {table }}$ where the value of $r_{\text {table }}$ lies at a value of 0.2352 , it can be concluded that the data is valid. Reliability test in research using the method Alpha Cronbach $(\alpha)$ and value $\alpha$ is obtained $>0.6$, so that the data is declared reliable.

From the results of the classical assumption test it is said that the research data is normally distributed due to significance $>0.05$. The data did not occur multicollinearity because the tolerance value was above 0.1 and the VIF value was below 10 and the research data did not occur heteroscedasticity due to the data significance of each variable is $>0.05$. 
Table 1. Multiple Linear Regression Test Result

\begin{tabular}{llrrr}
\hline & & \multicolumn{3}{c}{ Unstandardized } \\
\cline { 2 - 5 } Model & B & Std. Error & Sig. \\
\hline $1 \quad$ (Constant) & 7.234 & 1.943 & .000 \\
& Ethics & .329 & .089 & .000 \\
& Education Level & .254 & .088 & .005 \\
& Professional Skepticism & .351 & .117 & .004 \\
\hline Source: Processed SPSS Data, 2020 & &
\end{tabular}

Table 2. Determination Test Result

\begin{tabular}{ccc}
\hline Model & $\mathrm{R}$ & R Square \\
\hline 1 & $.927^{\mathrm{a}}$ & .859 \\
\hline
\end{tabular}

Source: Processed SPSS Data, 2020

According to Table 1, the following form obtained of multiple linear regression equation is:

$$
\mathrm{Y}=7.234+0.329 \mathrm{X}_{1}+0.254 \mathrm{X}_{2}+0.351 \mathrm{X}_{3}+\mathrm{e} .
$$

Based on the results of the partial test (Table 3), the ethical affects the audit quality. The results are in line with research conducted by Futri \& Juliarsa (2014), Nurjanah, \& Kartika (2016), and most recently by Ningsih \& Nadirsyah (2017). Auditors who adhere to professional ethics will not be easily influenced by other parties and carry out their duties in accordance with the ethical principles that apply to auditors, so that work quality standards will increase and will produce good quality audit results (Ningsih \& Nadirsyah, 2017). However, this research contradicts the research conducted by Ashari (2011) and Syafitri (2014) which states that ethics has no effect on audit quality.

The education level is affects the quality of the audit. The results are in line with research conducted by Futri \& Juliarsa (2014), and Widodo, et al. (2016). Due to professional care, in this case the high education level, there is a tendency for the quality of audit results to increase. However, this research is in contrast to the research conducted by Ningtyas and Aris (2016) which states that the education level has no effect on audit quality.

The professional skepticism is affects audit quality. The results are in line with research conducted by Azizah, et al. (2019), Nugrahaeni, et al. (2017), Ningsih \& Nadirsyah (2017), and Nurjanah \& Kartika (2016). Professional skepticism has a positive effect on the quality of internal audit because determining the professional skills. Professional skills will greatly affect the accuracy of giving an opinion by an auditor. Thus, it can be said that the higher the skepticism level of an auditor in conducting an audit, the more likely it will affect the accuracy of the auditor's opinion. The accuracy of giving the auditor's opinion can show good audit quality (Azizah, et al. 2019). However, the results of this study contradict the research of Tawakkal (2019) at the South Sulawesi Inspectorate that professional skepticism has no effect on audit quality.

Based on the results of the simultaneous test (Table 4), which states that the variables of ethics, education level and professional skepticism have an effect on audit quality.

Table 3. Parsial Test Result (t Test)

\begin{tabular}{llcccc}
\hline & \multicolumn{5}{c}{$\begin{array}{l}\text { Unstandardized } \\
\text { Coefficients }\end{array}$} \\
\cline { 2 - 6 } Model & $\mathrm{B}$ & Std. Error & $\mathrm{t}$ & Sig. \\
\hline \multirow{2}{*}{1} & (Constant) & 7.234 & 1.943 & 3.724 & .000 \\
& Ethics & .329 & .089 & 3.711 & .000 \\
& Education Level & .254 & .088 & 2.883 & .005 \\
& Professional Skepticism & .351 & .117 & 2.998 & .004 \\
\hline
\end{tabular}

Table 4. Simultaneously Test Result (F Test)

\begin{tabular}{llcccc}
\hline \multicolumn{2}{l}{ Model } & Sum of Squares & df & F & Sig. \\
\hline 1 & Regression & 2378.497 & 3 & 133.638 & $.000^{\mathrm{b}}$ \\
& Residual & 391.558 & 66 & & \\
& Total & 2770.054 & 69 & & \\
\hline
\end{tabular}

Source: Processed SPSS Data, 2020

Source: Processed SPSS Data, 2020

\section{DISCUSSION}

Overall, it can be said that auditors at the Inspectorate of West Java Province have referred to behavioral ethics that regulate the relationship between auditors and clients, between accountants and colleagues, and between the profession and the community. Referring to PP 60 concerning Government Internal Control, it is obligatory that as a professional organization to formulate a code of ethics for the government internal supervisory apparatus to maintain the behavior of officials who have the task of carrying out supervision. So far, the auditors have worked professionally, have high integrity, and are quite independent. Independence still has to receive more attention 
in producing audit quality, because independence can gradually decline due to the long interaction between the auditor and the object of examination which can establish kinship so that independence can be reduced. By applying ethics, auditors at the West Java Inspectorate are able to work honestly, maintain objectivity, and are able to be responsible and loyal to their work. This is in line with the statement of Arens, et al. (2017) which states that the auditor profession is a profession of public trust, so that an auditor in carrying out his professional duties is required to have full responsibility and cannot be separated from ethical problems.

The education level of auditors who work at the Inspectorate of West Java Province has met the requirements and is in accordance with generally accepted standards with the minimum education criteria being undergraduate program. The auditors are given several trainings and seminars related to their audit assignments on a regular basis. An auditor who has an adequate education level is expected to have broad insight so that the auditor is able to work optimally to improve audit quality. This is in line with the statement in Attachment 2 of the SPKN in 2017 which states that examiners who are assigned to carry out examinations according to inspection standards must collectively have competence, seen from their educational background, expertise and experience, as well as knowledge of inspection standards that can be applied to types of examination. commissioned examination. By going through the education level, auditors will have more knowledge (views) about the fields they work on so they can find out more about various problems, besides that auditors will find it easier to keep up with increasingly complex developments.

Inspectorate auditors already have professional skepticism. Auditors who have a skeptical attitude will work carefully and will not be quickly satisfied with the existing evidence, they will continue to study the evidence further. The auditors of the West Java Inspectorate always question evidence when performing audit assignments, if the evidence is deemed not valid, the auditor will not immediately make a report on the results of the examination but will first issue a narrative decision letter on the results of the examination to be completed and corrected by the object of the examination. Auditors who are disciplined in applying a skeptical attitude will easily detect if mistakes occur, they will continue to explore supporting evidence so as to produce quality audits. This is in line with the statement of Publik IAI (2001) which states that in performing their duties, an auditor must have a skeptical attitude. critical evaluation of audit evidence, because audit evidence is collected and assessed during the audit process, professional skepticism must be used during the process.

The quality of audits produced by the inspectorate is good, in terms of making sure the Inspectorate's report has recommendations that support it, however in terms of timeliness it must still be improved. This is due to the large number of findings so that the auditors of the Inspectorate of West Java Province issued a SK-NHP to be completed by the auditee before the issuance of the LHP and it needed time to return. Broadly speaking, the quality of the audit produced by the Inspectorate of West Java Province has been good, as evidenced by 9 consecutive times the West Java Inspectorate received a WTP opinion.

Simultaneously, ethics, education level, and professional skepticism affect audit quality. The results of this study are in accordance with the agency theory that the audit report can bridge the interests of the principal (government) and the agent/manager (ministry/institution) in managing finances. Auditors must have formal education in the field of accounting, especially mastery in the field of auditing, have a skeptical attitude in themselves so that they will not be easily satisfied with the evidence provided by the auditee, and must apply professional ethics in carrying out their audit duties. Through this series of activities, auditors will have higher certainty to carry out higher quality audits, so that the resulting audit report will also meet the requirements of a quality audit report.

It is in line with attribution theory which states that in producing a behavior, a person will be influenced by several factors both from within and outside the individual. In this study, attribution theory relates to the ability of auditors to produce audit quality. It will be influenced by several factors, both internal factors (professional skepticism) and external factors (ethics and education level).

\section{CONCLUSIONS}

Ethics, education level and professional skepticism simultaneously affect audit quality. Through the education level, auditors are able to detect auditing errors and through ethics and skepticism, auditors are able to report auditing errors. Ethics has a partial effect on audit quality and has the highest contribution. In performing their audit duties, the auditor has already referred to the professional code of ethics. The ethical indicators in this study have been fulfilled by auditors where the auditors already have and implement integrity and professionalism, but from the aspect of auditor independence, the Inspectorate of West Java Province still needs to be improved. Education level has a partial effect on audit quality and gave the lowest contribution because it may be that audit quality is produced by auditors with standard education according to the minimum criteria with lots of experiences. Professional skepticism affects audit quality means auditors at the Inspectorate of West Java Province have applied a skeptical attitude. 


\section{REFERENCES}

Arens, A.A., Elder, R.J., Beasley, M.S. and Hogan, C.E., 2017. Auditing And Assurance Services, 16th Global Edition. Michigan: Pearson.

Ashari, R., 2011. The Effect of Expertise, Independence, and Ethics on Auditor Quality at Inspectorate of North Maluku Province (Doctoral dissertation, Thesis).

Azizah, I., Wijayanti, A. and Fitrianne, W., 2019. Pengaruh Kualitas Auditor, Skeptisme Profesional, Komitmen Organisasi Terhadap Kualitas Audit Internal. In Prosiding Seminar Nasional Pakar (pp. 2-26).

Futri, P.S. and Juliarsa, G., 2014. Pengaruh Independensi, Profesionalisme, Tingkat Pendidikan, Etika Profesi, Pengalaman, Dan Kepuasan Kerja Auditor Pada Kualitas Audit Kantor Akuntan Publik Di Bali. E-jurnal Akuntansi, 7(2).

Ningsih, F. and Nadirsyah, N., 2017. Pengaruh Independensi, Skeptisisme Profesional Auditor, Penerapan Standar Audit, dan Etika Audit Terhadap Kualitas Hasil Audit (Studi pada Auditor BPK RI Perwakilan Provinsi Aceh). Jurnal Ilmiah Mahasiswa Ekonomi Akuntansi, 2(3), pp.48-58.

Ningtyas, W.A. and Aris, M.A., 2018. Independensi, Kompetensi, Pengalaman Kerja, dan Due Professional Care: Pengaruhnya Terhadap Kualitas Audit yang Dimoderasi dengan Etika Profesi (Studi Empiris pada Kantor Akuntan Publik se-Jawa Tengah dan DIY). Riset Akuntansi dan Keuangan Indonesia, 1(1), pp.75-88.

Nugrahaeni, S., Samin, S. and Nopiyanti, A., 2019. Pengaruh Skeptisisme Profesional Auditor, Kompetensi, Independensi Dan Kompleksitas Audit Terhadap Kualitas Audit. Equity, 21(2), pp.181-198.

Nurjanah, I.B. and Kartika, A., 2016. Pengaruh Kompetensi, Independensi, Etika, Pengalaman Auditor, Skeptisme Profesional Auditor, Objektifitas dan Integritas terhadap Kualitas Audit (Studi Pada Kantor Akuntan Publik Di Kota Semarang). Dinamika Akuntansi Keuangan dan Perbankan, 5(2).

Publik, I.A.I.K.A., 2001. Standar Profesional Akuntan Publik. Jakarta: Salemba Empat.

Syafitri, W., 2014. Pengaruh Keahlian, Independensi, Pengalaman Audit dan Etika terhadap Kualitas Auditor pada Inspektorat Provinsi Kepulauan Riau. Jurnal Universitas Maritim Raja Ali Haji Tanjung Pinang.

Tawakkal, U., 2019. Pengaruh Independensi, Integritas, Target Waktu dan Skeptisisme Profesional Auditor Terhadap Kualitas Audit. PARADOKS: Jurnal Ilmu Ekonomi, 2(2), pp.71-81.

Widodo, R.A.K., Pramuka, B.A. and Herwiyanti, E., 2016. Pengaruh Kompetensi, Tingkat Pendidikan Auditor dan Time Budget Pressure Terhadap Kualitas Hasil Audit. Jurnal Akuntansi, 10(1), pp.1-22. 